Volume 13

Issue 3 Critical Genocide and Atrocity

Prevention Studies

$12-20-2019$

\title{
Critical Genocide and Atrocity Prevention Studies
}

Andrew Woolford

University of Manitoba

Alexander Hinton

Rutgers University

Follow this and additional works at: https://digitalcommons.usf.edu/gsp

\section{Recommended Citation}

Woolford, Andrew and Hinton, Alexander (2019) "Critical Genocide and Atrocity Prevention Studies," Genocide Studies and Prevention: An International Journal: Vol. 13: Iss. 3: 1-8.

DOI:

https://doi.org/10.5038/1911-9933.13.3.1735

Available at: https://digitalcommons.usf.edu/gsp/vol13/iss3/3

This Editorial is brought to you for free and open access by the Open Access Journals at Digital Commons @ University of South Florida. It has been accepted for inclusion in Genocide Studies and Prevention: An International Journal by an authorized editor of Digital Commons @ University of South Florida. For more information, please contact digitalcommons@usf.edu. 


\section{Critical Genocide and Atrocity Prevention Studies}

Acknowledgements

Our thanks to the participants in the Critical Approaches to Genocide and Atrocity Prevention Workshop for their feedback on this introductory essay. 


\section{Guest Editorial: Critical Genocide and Atrocity Prevention Studies}

The frustrations of a genocide scholar are many. Chief among them is what Keith Tester refers to as the "rage" of the "incapacitated"1 - the paradox of having too much knowledge of human suffering but finding our selves unable to do little more than shout, "something must be done!" Institutions have become the primary moral agents for responding to terrible events like genocide, Tester notes, adding "It is not just the world which has been wholly institutionalized; our imaginations and horizons for moral action have been institutionalized as well." ${ }^{2}$ We seek to influence governments and other international actors to do something, and sometimes we even have suggestions as to what they should do. We also educate and raise awareness so that there might be public pressure that will spark the political will to act. But our action is always reliant on more powerful others to take on the challenge. And this displacement of agency allows us what Tester calls a "conceit of innocence," as though our rage is enough to remove our guilt of living in a world that allows and enables genocide. ${ }^{3}$

These frustrations are perhaps what led R.J. Rummel, an early contributor to the field of genocide studies and author of Death by Government, to pen a series of novels that imagine timetravelling, alternative-universe-hopping lovers who are set on a course to prevent the worst human atrocities. ${ }^{4}$ In the first book in the series, they seek to use their knowledge of genocide to create a peaceful world. But the actions they are willing to take to achieve this goal often leave them susceptible to Rummel's broader message that power kills. ${ }^{5}$ The novel betrays both a longing for meaningful intervention and a pessimism about the human condition. It should come as no surprise that Rummel sought to work through his experience as a genocide scholar by imagining counterfactual histories of key atrocity events.

Even when we are not working through fictional media, scholars are nonetheless engaged in emplotting narratives of genocide and its prevention. We draw upon interpretive grids to make meaning - frames - and within these frames we include the information necessary to present a sensible picture of genocide and its possible prevention. ${ }^{6}$ In the editing work of frames-making, information is, of course, left out. Characters are presented as inhabiting clear roles. The miseen-scène communicates the setting and the main line(s) of action. But beyond the frame, in what Alexander Hinton refers to as the "gutter," one finds other perspectives and experiences that have been pushed out of sight.?

For this special issue, we invited scholars working in the centers and peripheries of genocide studies to explore the gutters of prevention and to query what exists beyond our taken-for-granted frames. We prodded them to engage in acts of scholarly transgression, reclaim their "imaginations and horizons, ${ }^{\prime 8}$ interrogate the given categories and methods of the field, and let tensions multiply.

They have done so to different extents and different ways but always as part of open dialogue, first as part of a workshop, then in the process of peer review, and now in their iteration in this special issue and your reading of it. It is for this reason that, from the start, we were committed to publishing these essays in an open-access journal as opposed to one that lies behind a paywall or in an edited book.

\footnotetext{
${ }^{1}$ Keith Tester, Moral Culture (London: Sage, 1997), 7.

${ }^{2}$ Ibid., 7.

${ }^{3}$ Ibid., 8

${ }^{4}$ R.J. Rummel, Death by Government (New Brunswick: Transaction, 1994); R.J. Rummel, War E Democide Never Again (Plantation, FL: Llumina Press, 2004).

${ }^{5}$ Rummel, War \& Democide.

${ }^{6}$ Erving Goffman, Frame Analysis: An Essay on the Organization of Experience (Cambridge, MA: Harvard University Press, 1974). See also Alexander Laban Hinton, The Justice Facade: Trials of Transition in Cambodia (New York: Oxford University Press, 2018) and Alexander Laban Hinton, Man or Monster? The Trial of a Khmer Rouge Torturer (Durham: Duke University Press, 2016).

${ }^{7}$ Alexander Laban Hinton, "Critical Genocide Studies," Genocide Studies and Prevention 7, no. 1 (2012), 4-15; Alexander Laban Hinton, "Critical Genocide Studies," in Genocide Matters: Ongoing Issues and Emerging Perspectives, ed. Joyce Apsel and Ernesto Verdeja (New York: Routledge, 2013), 42-58.

${ }^{8}$ Tester, Moral Culture, 7.
}

Andrew Woolford and Alexander Hinton. "Critical Genocide and Atrocity Prevention Studies" Genocide Studies and Prevention 13, 3 (2019): 1-8. @2019 Genocide Studies and Prevention. 
Indeed, the paywall is perhaps an interesting way to consider the discipline of prevention, which is not just predicated on a set of conventional frames but also organizational forms, funding streams, status markers, domains of "influence," vernaculars, political and institutional power, and so forth - a "prevention paywall" if you will. Our intent as co-convenors of the workshop, co-editors of this special issue, and co-authors of this introduction is to step into the gutters of prevention and thereby help destabilize the frames undergirding this prevention paywall. It is an endeavor that requires openness and dialogue, not foreclose.

To this end, this brief introduction offers four ways in which the contributors have stepped into the gutters of prevention. We invite you to join us in our endeavor to rethink prevention, one that, as with Rummel's time-travelers, requires a willingness to reconsider the taken-for-granted and envision new possibilities. If "capacity" refers to the ability to contain, it also suggests "intellectual power" and ability creating "a possibility." ${ }^{\prime \prime}$ One modest response to the rage of the incapacitated is to create such new possibilities by rethinking prevention.

\section{Critique is Prevention}

Critique is a first key pathway for this critical genocide studies and prevention. In the spirit of Derrida, who defended his work against critics who suggested deconstruction is an amoral practice unable to take a stand on key social issues, these contributors suggest that "critique is prevention."

In the aftermath of the Paul de Man affair, when the literary scholar and practitioner of deconstruction was discovered to have been a past Nazi sympathizer, embezzler and bigamist, Derrida found not only his friendship with de Man, but his entire intellectual project called into question. ${ }^{10}$ The fact that deconstruction undercuts the Western tradition of reasoned decisionmaking was viewed to authorize the unprincipled actions of de Man. More seriously, it potentially placed Derrida among the camp of philosophers, such as Heidegger and Schmidt, perceived to be in sway to authoritarianism. ${ }^{11}$ By refusing to privilege modern practices of judgment and reason, deconstruction was accused of creating space for an authoritarian will to power to impose its own order.

In a presentation to the Cardozo Law School, which would become his essay "Force of Law," Derrida offers a sophisticated apologia for deconstruction. The broader complexity of this essay is beyond the scope of this introduction; what is most pertinent to our discussion is how he presents the need for critical practices of deconstruction when contemplating justice as an "experience of the impossible." Because justice is never final or fixed, since it represents an ideal horizon that is always "to come," our efforts to achieve justice are simply calculations, or decisions, that attempt to approximate justice.

This is where the "force" of law comes into play, as particular calculations of an incalculable justice require the force of decision to assert them as universal law. Deconstruction, by offering a technique for interrogating the arbitrary and "mystical" force of such decisions, provides a means for keeping open aporias, or paradoxes, of justice so they are not facilely resolved.

For example, Derrida reflects on the aporia that we feel an urgency to act in the face of injustice while, at the same time, we require an infinite amount of information to act justly. Any response we make to a perceived injustice must be understood as a fallible, partial response. Deconstruction ensures that any such decision to act will be subject to critical interrogation. ${ }^{12}$

What is genocide prevention if not a form of decision-making in the name of justice? In order to imagine a possible intervention, researchers and policy-makers make multiple decisions, including assessing which signs and signals denote an oncoming crisis and which counter-measures will be

\footnotetext{
9 "Capacity," Shorter Oxford English Dictionary, 2007.

${ }^{10}$ Matters were not helped by Derrida's book Memoires: Pour Paul de Man (Paris: Éditions Galilée, 1988), published shortly after de Man's death, which many read as an exculpatory treatise that took too lightly de Man's antisemitism. Given Derrida's prior efforts to speak out against anti-Semitism, his delay in grappling critically with the de Man affair caused a certain amount of disappointment, and led to further questioning of the ethics of deconstruction.

${ }^{11}$ John McCormick, "Derrida on Law; Or, Poststructuralism gets Serious," Political Theory 29, no. 3 (2001), 395-423.

${ }^{12}$ Jacques Derrida, "Force of Law: The Mystical Foundation of Authority," in Deconstruction and the Possibility of Justice, eds., Drucilla Cornell, Michael Rosenfeld, and David Gray Carlson (New York: Routledge, 1992), 3-67.
} 
most effective in preventing atrocity crimes. There is a need to act, and questioning the decisions that are made in a rush to prevent can seem impractical or even a distraction. But each act of prevention is a fallible calculation, necessitating rather than ruling out critique.

As cultural theorist Gayatri Spivak has argued with respect to the genocide of the Rohingya, there is also a need for impractical thinking in the face of genocide, since it is only through imaginative, impractical thinking that we can approach an understanding of our common humanity with a targeted Other like the Rohingya, while at the same time, granting them their own history. ${ }^{13}$

The contributors to this special issue call upon multiple critical theorists to argue for the practicality of a seemingly impractical critique. Andrew Woolford, Adam Muller, and Struan Sinclair reference Wendy Brown's argument that critique is a means to prevent foreclosing the present and stultifying imagination, in addition to employing Deleuze and Guattari's language of the molar and the molecular to critically assess predominant genocide prevention metaphors. Ernesto Verdeja conjures up the spirit of the Frankfurt School and its emancipatory project in contradistinction to allegedly value-free research. Alexander Hinton weaves Barthes, Foucault, and Derrida into his recounting of critical prevention stories that operate to unpack some of the baggage we bring with us to the study of genocide prevention. And Jobb Arnold gathers an eclectic theoretical crowd of Sara Ahmed, Glen Coulthard, and Claudia Card, among others, in his emphasis on fostering social vitality over simple prevention.

In each of these nods to well-known critical theorists, what we see is not rote application of fashionable theory. Nor is it simply name-dropping for purposes of demonstrating cultural capital. These theorists are not erected as part of a jargon-laden paywall meant to only allow the initiated into this issue. Instead, concepts and ideas are redeployed to bring the spirit of critique into genocide prevention studies. They are used to burst open familiar ways and patterns - that is, to be for a moment, as Spivak urges, impractical so that new possibilities of practical thinking open up within our field.

This is not to say that the research undertaken by those currently working on genocide prevention is not in its own way critical. Certainly, when decisions are made about how to predict, assess and respond to potential crises, critical tools are employed to assist in making a judgment. This can be done, for example, by assuming there exists a normal or stable state of social life, and measuring against this norm the destabilizing forces that portend a crisis.

Verdeja in this issue refers to this as the "teleology" of genocide prevention, which is often a western liberal-democratic norm. This norm becomes the criterion against which the crisis, and therefore need for prevention, is measured. The existence of such a norm allows for critical evaluation to the extent that societal stability is assessed against this norm, enabling for criticisms of those societies that fail to match the ideal.

This is not, however, the way we envision the idea that "critique is prevention." While critical work, such as that performed in most genocide prevention studies, engages in judgment by evaluating a social situation against an expressed or unexpressed criterion, critique endeavors to interrogate all criteria. Our sacred truths, our heretofore unexamined positionality, and (gasp) maybe even Raphael Lemkin are exposed to questioning. Critique is prevention because, to return to Derrida, it challenges the force of genocide studies and genocide prevention.

The force of genocide prevention refers to more than the violence of military intervention, such as that carried out as a last resort under the Responsibility to Protect, as discussed by Daniel Feierstein in this special issue. Military violence, as Feierstein shows, begets further violence, ${ }^{14}$ and is too often distributed based on arbitrary (rather than just), self-interested criteria - such as when Libya is selected for intervention while Honduras is not. But even when genocide prevention does not reach the point of military intervention, it is still susceptible to performative contradiction when not accompanied by critique.

In other words, it answers perceived violence with a violence of its own. This is arguably a lesser violence, one that includes imposing meaning on complex situations, translating local

\footnotetext{
${ }^{13}$ Gayatri Spivak, "Public Lecture: The Rohingya Issue in a Global Context," Hollis E. Cornell Auditorium, Goldwin Smith Hall, Cornell University, Ithaca, NY, October 30, 2017, accessed October 1, 2019, https://www.cornell.edu/video/ gayatri-spivak-rohingya-issue-global-context.

${ }^{14}$ See also Alan Kuperman, “Did the R2P Foster Violence in Libya?" Genocide Studies and Prevention 13, no. 2 (2019), 38-57.
} 
experiences into universal narratives, creating normative criteria for assessment based upon a Western cosmology, and disguising self-interest and geopolitical maneuvering as justice. But it is a violence, nonetheless, and one that threatens to undermine the ethos of genocide prevention, which, in general, seeks to make room for collective vitality and flourishing.

When genocide prevention comes under question, perhaps as a form of neocolonialism or geopolitics by other means, the ethos of genocide prevention is potentially compromised because collective persistence is subsumed under other interests. Critique prevents genocide prevention from ignoring its blind spots, becoming habituated to Western norms and reason, and failing to imagine possibilities beyond the current geopolitical arrangement. Critique can even lead us to question the basic axiological and categorical commitments that underpin the project of genocide prevention, leading us to ask, among other questions: What is a group? Where do its boundaries begin and end? What actions threaten its discussion? And which types of groups do we choose to protect and which do we ignore?

\section{Pathways to a Critical Genocide Prevention Studies}

This sort of critique opens space for new visions of prevention, ones the contributors explore in various ways even as this special issue offers only a sampling of the variety of interventions possible through a critical genocide prevention studies lens. In addition to and often in the spirit of critique, the essays that follow step into the gutters of prevention in various ways including by exploring: a) Genealogies of Prevention and Interdisciplinary Modularity; b) Scalar Interventions and Chronotopes of Genocide Prevention; c) The Practice and Performance of Critique; and d) Critical Epistemologies of Prevention.

There are other possibilities for critique as prevention, some still to emerge, as one would expect from a transgressive scholarly practice. Indeed, all of the papers presented here can and should be pushed to take their critical project further. We invite readers of this journal to engage and critique our work - in the open spirit of Roland Barthes' "writerly" as opposed to the monologic authority of "the readerly" - as Hinton discusses in his contribution.

\section{Genealogies of Prevention and Interdisciplinary Modularity}

A starting point for the critique of genocide prevention is quite often an examination of how we got to the place we are at now. There is no one trajectory for understanding the development of genocide prevention as a distinct subfield of investigation within the genocide studies discipline. In this special issue, there are different, yet complementary genealogies of emergence. The genealogical method involves unearthing the development of things we take for granted, such as the logic of prevention, without assuming their naturalness or inevitability. ${ }^{15}$

In their paper, Woolford, Muller, and Sinclair examine the origin story of this journal and the rationale Israel Charny and Roger Smith provided for including the word "Prevention" in its title. They connect this idea of prevention, found also in Lemkin's thought, to late modern "risk society," when tools of prediction and actuarial science fostered the sense that global risks could be calculated, making intervention possible.

Verdeja emplots the rise of prevention slightly differently, situating it within a liberal orientation and accompanied by an emergent human rights regime designed to establish international rule of law. Feierstein, likewise, points to the growth of universal jurisdiction as a means of breaking through the impunity that comes with an entrenched sovereignty. But he also sees universal jurisdiction transformed into a global policing strategy as an "international criminal justice approach" takes hold.

As Hinton reminds us in his article, there are many stories we tell ourselves about genocide and prevention. This variance means there is also potential to use counter histories to emplot critical genocide prevention studies in a different manner. These counter-histories need not solely be studies of the emergence of genocide prevention. They can also focus on specific genealogical moments. In this vein, Kerry Whigham in his article examines the notion that some conflicts are "intractable" and how this language circumscribes the possibility of conflict transformation. Julia

\footnotetext{
${ }^{15}$ Michel Foucault, "Nietzsche, Genealogy, History," in Language, Counter-memory, Practice, ed. Donald F. Bouchard, trans. Donald F. Bouchard and Sherry Simon (Ithaca: Cornell University Press, 1977), 139-164.
} 
Zulver, as well, questions the representation of women in the genocide prevention literature solely as peacemakers, and the consequences of this limiting role assignment. New stories can be told about genocide prevention in a manner that opens space for critical insight.

Genealogical interventions arise not only through discussions within the discipline, but also by broadening the field. Although genocide studies prides itself as a multidisciplinary field, research in this field has traditionally been informed by a relatively narrow range of disciplines, including political science, law, history, sociology, and psychology. There remain opportunities for engagement with other fields. This is what we mean by Interdisciplinary Modularity as a form of critical intervention. Through interdisciplinary bridging, expansion, or analogy, the habits and assumptions of genocide studies can shift and grow.

In this special issue, several authors adopt and adapt lessons from research in areas such as civil war studies, anthropology, ecology, and Indigenous studies to expand or re-orient the direction of genocide prevention studies. Along these lines, Arnold connects Card's well-known work on social death with Antonovsky's salutogenetic model of health and Ahmed's work on emotions and affect. And through this assemblage of ideas, he brings to light the ways local actors promote social vitality and cohesion for their groups.

For Whigham, the dramaturgical approach of performance studies offers inspiration for thinking about how individuals enact scenarios that lead beyond intractable conflict. Zulver is influenced by research on women's social movements to examine the diverse agency of women in situations of "high risk feminism." Finally, Hinton pushes further past field boundaries, stirring mythology, comic books, translation, and archaeology into the interdisciplinary cauldron. Genealogy exposes contingencies in the development of genocide prevention as an area of study. Modularity takes this contingency as an invitation to further re-shape the field. Deprived of an unassailable foundation, genocide prevention studies can take on the multivocality Verdeja and Hinton promote in their articles drawing on varied levels of analysis, representational and literary strategies, conceptual schemes, and methodologies so as not to become ossified in its practice.

\section{Scalar Interventions and Chronotopes of Genocide Prevention}

As with Interdisciplinary modularity, scalar interventions are meant to reposition the study of genocide studies by suggesting genocide prevention cannot simply be measured at one scale. In this sense, the prevention research and scholarship needs to be multi-scalar -- or at least keep an eye on other scales. Andrew Woolford's "mesh" model provides an illustration of how this can be done. ${ }^{16}$

Several contributors similarly point to the importance of micro-level scales for assessing the efficacy of genocide prevention, as can be seen in the articles by Whigham, Arnold, and Woolford, Muller, and Sinclair. Hollie Nyseth Brehm and Verdeja also give attention to local and regional variations in genocidal processes, but their interventions are more fully multi-scalar in that they call for genocide prevention studies to move beyond a fixation on state-level research. Zulver shares this concern, noting how women are often only considered as micro-level actors, rather than having roles to play at meso-, macro-, or even global levels.

In James Waller's article, the scalar positioning is presented somewhat differently, conceived as placed either upstream, midstream, or downstream from the conflict. This metaphor suggests not only spatial proximity to conflict but also temporal proximity, since upstream represents the time and space before the event, midstream is within the moment of crisis, and downstream addresses its results. This configuration of time and space brings to mind Mikhail Bakhtin's notion of the chronotope, the admixture of an always-entangled space and time, and its relevance to critical prevention. ${ }^{17}$

Too often, our attention is turned to either time or space. Though she does not use the term "chronotope," Brehm's examination of sub-regional patterns of genocide in Rwanda are an effective illustration of the chronotope and its amalgamation of space/time. Whereas state-level

\footnotetext{
${ }^{16}$ Andrew Woolford, This Benevolent Experiment: Indigenous Boarding Schools, Genocide, and Redress in Canada and the United States (Lincoln: University of Nebraska Press, 2015).

${ }^{17}$ Mikhail M. Bakhtin, The Dialogic Imagination (Austin: University of Texas Press, 1981); Mariana Valverde, Chronotopes of Law: Jurisdiction, Scale and Governance (London: Routledge, 2015).
} 
analyses spatialize and temporize the Rwanda genocide as a nation-wide phenomenon beginning in April 1994, chronotopic analysis illustrates the ebbs and flows of the genocide, as it sparks first in specific regions before heating up in others. Feierstein's critical analysis of differential responses to mass violence also brings to mind the chronotope, as geopolitical and historical factors collide in determining where/when prevention is deemed to be needed (e.g., Libya) and where/when it is not (e.g., Yemen, Honduras, Turkey).

With time and space comes attention to movement, as consideration of the flows of genocide -- including its pace (fast or slow) -- brings awareness of pulsating, oscillating, and cyclical patterns of violence that trouble linear models of prevention (see Verdeja, Woolford, Muller, and Sinclair, and Waller). When the goal is to interrupt the process of genocide, the scale, chronotope, and flow of genocide are matters of great importance.

\section{The Practice and Performance of Critique}

Critique must not be directed solely outward. The target is not a set of scholars or practitioners who are branded "mainstream" or "conservative" or by some other label. When the practices of genocide prevention are subject to critique, these practices include not only those that are perceived to be most prevalent, but also our own. Such reflexivity is at the heart of critique. For this reason, critical scholars tend to offer tools or guidelines for improving critical practice, or through their writing, seek to perform alternative ways to engage with our subject matter.

Tools of critical practice can include deconstruction, decentering, frame-shifting, multiple perspective-taking, and exposure of blind spots, among other techniques. Many of these tools, and others, are on display in this special issue. Zulver decenters a seemingly gender-neutral prevention studies to create space to examine women's agency, while at the same time troubling notions of women and women's mobilization.

Woolford, Muller, and Sinclair discuss the tendency toward linear and molar representations in the genocide prevention and gesture toward a more rhizomatic and molecular understanding of prevention. And, in addition to suggesting that critical genocide prevention studies should be anti-teleological and multivalent, Verdeja also provides guidance as to how self-reflective and dialectical approaches are needed within this area of study.

Waller's contribution to this volume also serves an important critical role. He challenges the critics to better communicate the complexity and urgency of genocide prevention to political actors. In this manner, his article also offers a performative example of the practice of critique. He illustrates how one must turn critique back upon oneself and consider the end goals of our endeavors.

In a different way, Feierstein and Hinton also exhibit performances of critique. In Feierstein's provocation, the art of provocation is fully on display. Academics are often trained to hedge, balance, or even equivocate, the provocateur plays an important role in shaking us from our stupor. In Feierstein's case, his provocation comes in the form of a discomforting exposé of the contradictions and limitations of preventative practice.

Hinton's piece in itself is a performance of critique in the sense that the very act of writing is intended to overturn conventions of genocide prevention studies and academic scholarship more generally. It offers multivocality, juxtaposition, recursion, and contested meanings to break us free from the habits of our research and to alert us to how the cures we proffer may also carry poison within them. To encourage such reflexivity, he offers a "first lesson in critical prevention," one encapsulated in a warning given in the opening line of his essay.

\section{Critical epistemologies of prevention}

The critical interventions all raise questions about how we know what we claim to know about genocide and its prevention. They also present opportunities to know genocide and prevention differently. With respect to the former, Feierstein challenges the data often used to support socalled humanitarian intervention. By alerting readers to rates of violence and displacement in nations not typically considered in need of intervention, he exposes the contingency of decisions to intervene under the responsibility to protect. 
Whigham directs our gaze more toward local ways of knowing, and suggests that "flipping the script" can allow local actors to know their conflicts differently and overcome intractability. Likewise, Woolford, Muller, and Sinclair look to new technologies, such as virtual reality, to allow people to know their social world differently and thereby contribute to the prevention of further cultural destruction of Indigenous peoples in Canada.

Critical epistemologies of genocide prevention are a means to disrupt or transgress the frame, to find our way to the gutter. As Hinton's essay shows, we can carefully excavate the tools that enable and authorize our research and allow us to tell a story about genocide and its prevention. If critique is prevention it is also prevention against becoming too invested in our own professional expertise and the narratives of genocide and prevention we are empowered to create. By excavating our tools and permits, as Hinton shows, we become aware of our investments, the frames we construct, and some of what lies beyond them.

Critical prevention studies, and critical genocide studies, remain areas that are still in their infancy. However, understanding that critique is prevention compels us toward a different understanding of prevention: one that is ongoing, adaptable, relational, reflexive, fallible, and multi-perspectival. In this manner, critique transforms prevention into something more reflexive and consistently active.

Whereas prevention can suggest a surgical cut, a wound opened and closed to avert some greater threat, critique as prevention suggests something more persistent and dynamic. Like Arnold's used of the salutogenetic model, it suggests an always "to come" health that can only be supported through attention to multiple factors.

Rather than a "responsibility to protect" it suggests what Harroway describes as "responseability," which is not a liberal obligation to act in a singular manner but rather a relational praxis of attention and response to the troubles we face. We enact response-ability not just through facts, but also recognition of the stories we tell-and by joining different stories together, we open up our frames of genocide prevention to the new possibilities demanded by the challenge of Tester's rage of the incapacitated.

Andrew Woolford Alexander Hinton

\section{Acknowledgements}

Our thanks to the participants in the Critical Approaches to Genocide and Atrocity Prevention Workshop and the GSP editors for their feedback on this introductory essay.

\section{Bibliography}

Bakhtin, Mikhail M. The Dialogic Imagination. Austin: University of Texas Press, 1981.

Derrida, Jacques. "Force of Law: The Mystical Foundation of Authority." In Deconstruction and the Possibility of Justice, edited by Drucilla Cornell, Michael Rosenfeld, and David Gray Carlson, 3-67. New York: Routledge, 1992.

------. Memoires: Pour Paul de Man. Paris: Editions Galilée, 1988.

Foucault, Michel. "Nietzsche, Genealogy, History." In Language, Counter-memory, Practice, edited by Donald F. Bouchard, Translated by Donald F. Bouchard and Sherry Simon, 139-164. Ithaca: Cornell University Press, 1977.

Goffman, Erving. Frame Analysis: An Essay on the Organization of Experience. Cambridge, MA: Harvard University Press, 1974.

Hinton, Alexander Laban. "Critical Genocide Studies." Genocide Studies and Prevention 7, no. 1 (2012), 4-15. Doi 10.3138/gsp.7.1.4

---------. “Critical Genocide Studies." In Genocide Matters: Ongoing Issues and Emerging Perspectives, edited by Joyce Apsel and Ernesto Verdeja, 42-58. New York: Routledge, 2013.

Kuperman, Alan. "Did the R2P Foster Violence in Libya?" Genocide Studies and Prevention 13, no. 2 (2019), 38-57. Doi: 10.5038/1911-9933.13.2.1705

McCormick, John. "Derrida on Law; Or, Poststructuralism gets Serious." Political Theory 29, no. 3 (2001), 395-423. Doi: 10.1177/0090591701029003004

Rummel, R. J. Death by Government. New Brunswick: Transaction, 1994. -. War \& Democide Never Again. Plantation, FL: Llumina Press, 2004. 
Spivak, Gayatri. "Public Lecture: The Rohingya Issue in a Global Context." Hollis E. Cornell Auditorium, Goldwin Smith Hall, Cornell University, Ithaca, NY, October 30, 2017. Accessed October 1, 2019. https://www.cornell.edu/video/gayatri-spivak-rohingya-issueglobal-context.

Tester, Keith. Moral Culture. London: Sage, 1997.

Valverde, Mariana. Chronotopes of Law: Jurisdiction, Scale and Governance. London: Routledge, 2015.

Woolford, Andrew. This Benevolent Experiment: Indigenous Boarding Schools, Genocide, and Redress in Canada and the United States. Lincoln: University of Nebraska Press, 2015. 